\title{
Micrometeorological conditions of the soloteca of Embrapa Solos - Rio de Janeiro, Brazil
}

DOI: $10.53499 /$ sfjeasv1n2-001

Received in: February 1st, 2021

Accepted in: March 31th, 2021

Evaldo de Paiva Lima

$\mathrm{PhD}$ in Agricultural Meteorology from the Federal University of Viçosa

Institution: Embrapa Solos / UEP Recife

Address: Rua Antônio Falcão, 402 - Boa Viagem, Recife - PE, Brazil

E-mail: evaldo.lima@embrapa.br

Rosandro Boligon Minuzzi

$\mathrm{PhD}$ in Agricultural Meteorology from the Federal University of Viçosa

Institution: Universidade Federal de Santa Catarina

Address: Rodovia Admar Gonzaga, 1346 - Itacorubi, Florianópolis - SC, Brazil

E-mail: rosandro.minuzzi@ufsc.br

Yuri de Almeida Lyra Corrêa

Technician in Meteorology from the Celso Suckow da Fonseca Federal

Center for Technological Education

Institution: Infnet Institute

Address: Rua São José, 90 - Centro, Rio de Janeiro - RJ, Brazil

E-mail: yuricorreapele@gmail.com

\section{Camila Sanches de Oliveira}

Technician in Meteorology from the Celso Suckow da Fonseca Federal

Center for Technological Education

Institution: Universidade do Estado do Rio de Janeiro

Address: Rua São Francisco Xavier, 524 - Maracanã, Rio de Janeiro - RJ, Brazil

E-mail: sanches_camila28@yahoo.com

\begin{abstract}
Soloteca is the term used in Brazil to refer to the place where reference soil samples are stored. The Soloteca of Embrapa Solos - Rio de Janeiro, for example, stores soil samples from different regions of Brazil, and these samples need to be stored in conditions that preserve their intrinsic characteristics. In this context, the objective of this work was to determine the air temperature and relative humidity conditions in the Soloteca of Embrapa Solos. The data were collected by three Thermo hygrometers, installed inside and outside the place where the samples are stored, in the period from December 1, 2016, to March 31, 2017, corresponding to summer 2016/17. The difference between the average and variance of the data for each environment/height was evaluated at the 5\% level, respectively, by the t-Student and Snedecor's F tests. The other statistical analyses were presented by boxplots. It was observed that the air temperature, on average, did not differ between the indoor and outdoor environments at a height of 1.6 meters, but there was a difference with the sensor installed near the surface ( 0.5 meters). On the other hand, the dispersion of the data attested by the variance and the coefficient of variation in the external environment was greater than those recorded internally.
\end{abstract}

Keywords: Air temperature, relative humidity, soil sample storage. 


\section{INTRODUCTION}

Soloteca $($ from Greek, theca $=$ deposit) or Pedoteca $($ from Greek, pedon = soil; earth) are the terms used in Brazil to refer to the place where the reference soil samples are kept, which are those typical of a certain region and taxonomic class. It constitutes a true collection in which each of the specimens is duly identified and characterized from the pedological point of view (morphological, physical, chemical, and mineralogical data). Like a library, it has three main objectives: (a) to store the soil samples in a place free of danger; (b) to conserve the samples so that no alteration occurs in their intrinsic characteristics; and (c) to organize the soil samples according to rules of cataloging, classification, indexing and archiving, in such a way that it is possible, in an immediate way, to consult the information about them (soil class, collector, municipality, geographic coordinates, sample quantity, etc.) and to retrieve them for research and teaching purposes. Therefore, a Soloteca must have a physical part, which is the stock of samples, and a digital part, which is the data generated and stored digitally.

According to Boone et al. (1999), archiving soil samples is an essential component of a longterm soil research program. Archived soils are invaluable "time capsules" for assessing temporal changes in soil properties, particularly as new analytical tools become available. The work of Friedland et al. (1992) is cited as an example of the importance of storing soil samples. These authors showed a reduction in lead levels at several locations in the Northeastern United States after the use of lead in gasoline was discontinued.

There are several recommendations for the long-term storage of reference soil samples. However, the ideal limits of air temperature and relative humidity for the storage of samples in a Soloteca were not found in the literature. In this sense, Boone et al. (1999) commented on at least three precautions regarding the micrometeorological conditions: (a) samples should be kept air-dried at room temperature in a safe location with a low probability of water damage (e.g., broken pipes, floods or storms), chemical contamination, fire, or other catastrophes; (b) air temperature fluctuations should be minimized because of the potential for condensation within containers, and (c) dehumidification may be necessary during warmer months.

The Soloteca of Embrapa Solos, which is a division of the Brazilian Agricultural Research Corporation (Embrapa), is older than Embrapa itself and is located in the city of Rio de Janeiro, RJ. Its origin, however, is not documented. According to a personal statement from Humberto Gonçalves dos Santos, who was a researcher at Embrapa Solos, there was already a place for storing soil samples since his arrival, in October 1964, at the now-extinct Department of Agricultural Research and Experimentation (DPEA), which was headquartered where Embrapa Solos is today. The aforementioned researcher, who, being one of the oldest researchers, ended up becoming a source of information on past 
events, supposed that the Soloteca had been created in the period 1947-50, on the occasion of the creation of the Soil Commission that started the first soil surveys in Brazil (Laforet et al., 2014).

It is of great importance to know the micrometeorological conditions of the Soloteca of Embrapa Solos, which has reference soil samples that were collected in different regions of Brazil. In this context, the objective of this work was to determine and compare the conditions of air temperature and relative humidity during the summer at the Soloteca of Embrapa Solos - Rio de Janeiro, Brazil.

\section{MATERIALS AND METHODS}

The Soloteca is located at Embrapa Solos $\left(22^{\circ} 58^{\prime} 16^{\prime \prime} \mathrm{S}, 43^{\circ} 13^{\prime} 27^{\prime \prime} \mathrm{W}, 3.0 \mathrm{~m}\right.$ ), which is headquartered in the city of Rio de Janeiro, Rio de Janeiro State (RJ). According to the Köppen-Geiger methodology, the city's climate is classified as Am (tropical monsoon), with a rainy period from October to April. The air temperature and annual average rainfall are $22.1^{\circ} \mathrm{C}$ and $1,390 \mathrm{~mm}$, respectively. July is considered the coldest and driest month, with $18.5^{\circ} \mathrm{C}$ and $49 \mathrm{~mm}$. However, the month of January presents the highest air temperature $\left(25.1^{\circ} \mathrm{C}\right)$ and precipitation $(185 \mathrm{~mm})$, according to Alvares et al. (2013).

The Soloteca (Figure 1a) is installed in a well-maintained masonry structure with dimensions of $10 \mathrm{~m}$ long x $7.30 \mathrm{~m}$ wide x $5.30 \mathrm{~m}$ high. The environment holds 47 metal shelves of different dimensions, and its estimated maximum storage capacity is 20,000 to 25,000 samples, depending on the dimensions of the containers in which they are stored (Figure $1 b$ ).

Figure 1. Soloteca of Embrapa Solos (a) and the storage of samples inside (b).

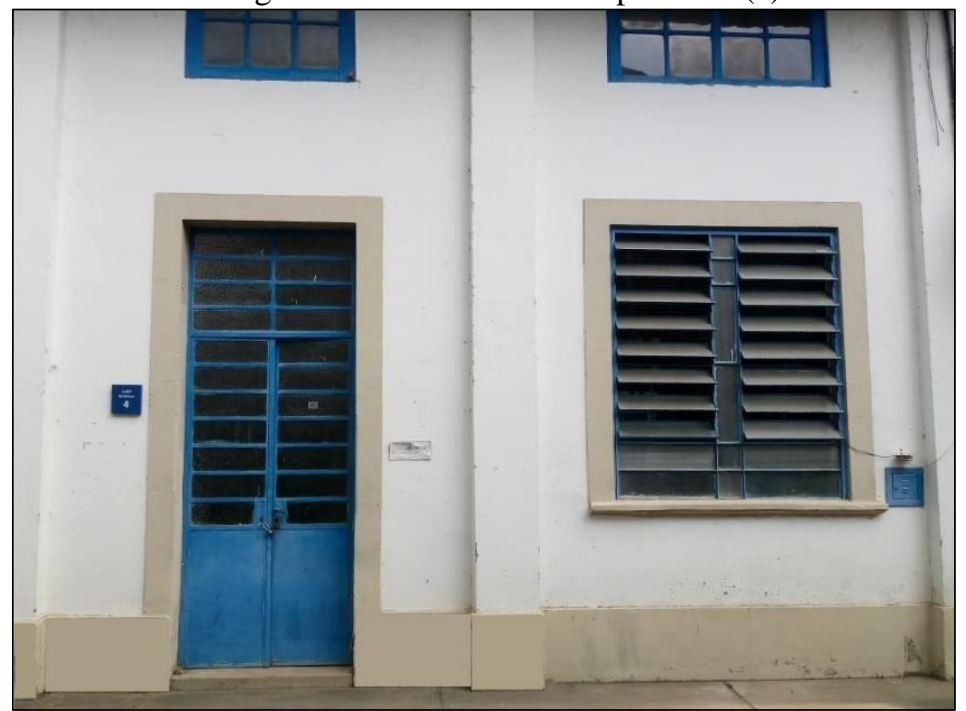

(a)

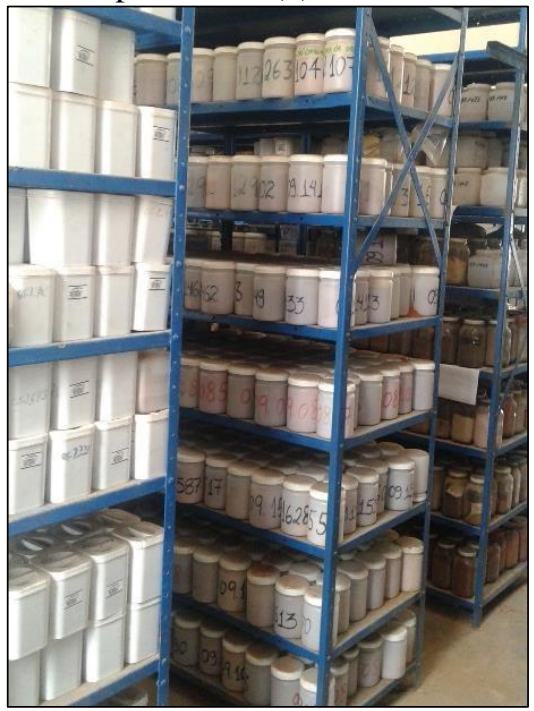

(b) 
Hourly air temperature and relative humidity data were collected during the period from December 1, 2016, to March 31, 2017, corresponding to summer 2016/17. The data were recorded by three Thermo hygrometers ("EHT Temperature/RH Sensor"), which were connected to the Em50 datalogger from Decagon, and were installed in three different locations: $1.6 \mathrm{~m}$ and $0.5 \mathrm{~m}$ high in the internal area (Figure 2a), and $1.6 \mathrm{~m}$ high in the external area (front wall) of the Soloteca (Figure 2b). It is worth mentioning that, due to problems in one of the Thermo hygrometers, the relative humidity results for the sensor installed at $0.5 \mathrm{~m}$ height (internal area) will not be presented. The air temperature sensor has a resolution of $0.1^{\circ} \mathrm{C}$ and an accuracy of $\pm 0.3^{\circ} \mathrm{C}$, for measurements between 15 and $50^{\circ} \mathrm{C}$. The relative humidity sensor has a resolution of $0.1 \%$ and precision of $\pm 2 \%$, for measurements between 25 and $90 \%$ and air temperature between 20 and $30^{\circ} \mathrm{C}$.

Figure 2: Sensors installed, with datalogger, inside (a) and outside (b) of the Soloteca.

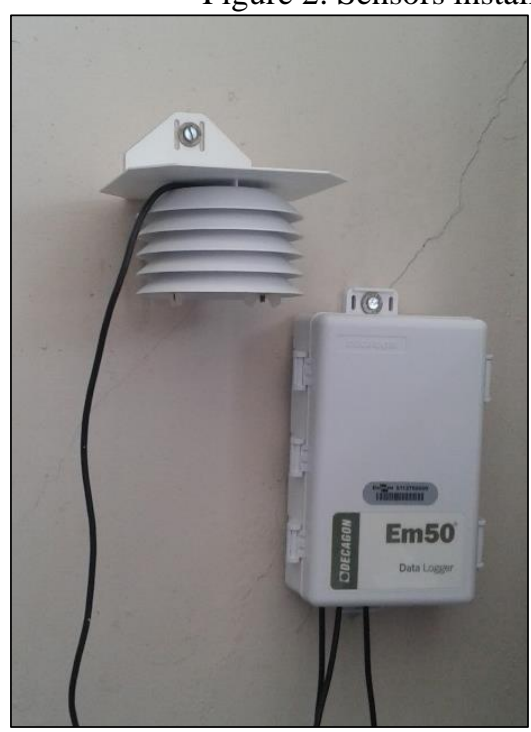

(a) Internal sensors

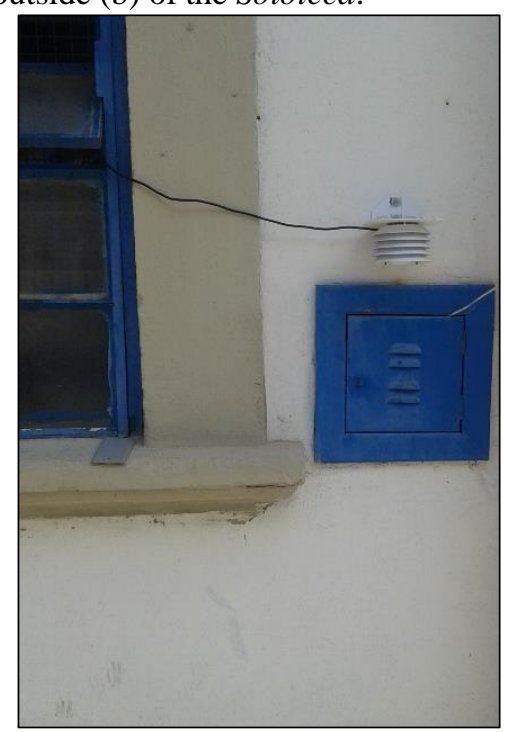

(b) External sensors

The difference between the average and variance of the data of each environment/height was evaluated at 5\% level, respectively, by the t-Student and Snedecor's F test, according to Costa Neto (2002). The other statistical analyses of air temperature and relative humidity will be presented by boxplots.

\section{RESULTS AND DISCUSSION}

Table 1 shows the average, variance, and coefficient of variation of the air temperature and relative humidity measured in the indoor and outdoor environments of the place where the reference soil samples are stored. 
Table 1. Average, variance ${ }^{1}$ and coefficient of variation $(\mathrm{CV})$ of air temperature and relative humidity measured in the internal (Int) and external (Ext) environments of the Soloteca.

\begin{tabular}{lcccccc} 
& \multicolumn{3}{c}{ Air temperature $\left({ }^{\circ} \mathrm{C}\right)$} & \multicolumn{2}{c}{ Relative humidity $(\%)$} \\
\cline { 2 - 6 } & Indoor-1.6m & Indoor-0.5m & Outdoor-1.6m & Indoor-1.6m & Outdoor-1.6m \\
\hline Average & $27.6 \mathrm{a}$ & $26.9 \mathrm{~b}$ & $27.6 \mathrm{a}$ & $71.3 \mathrm{a}$ & $70.7 \mathrm{a}$ \\
Variance & $3.4 \mathrm{a}$ & $3.0 \mathrm{a}$ & $4.8 \mathrm{~b}$ & $19.7 \mathrm{a}$ & $37.3 \mathrm{~b}$ \\
$\mathrm{CV}(\%)$ & 6.6 & 6.4 & 8.0 & 6.2 & 8.6 & 8.2 \\
\hline
\end{tabular}

${ }^{1}$ Averages and variances with the same letter between columns for temperature and relative humidity do not differ significantly from each other at the $5 \%$ level, respectively, by Student's t-test and Snedecor's F-test.

It is observed that the air temperature, on average, did not differ between the indoor and outdoor environments at a height of 1.6 meters, but there was a difference with the sensor installed near the surface $(0.5$ meters). On the other hand, the dispersion of the data attested by the variance and the coefficient of variation (CV) in the outdoor environment was greater than those recorded indoors. As an example, we can cite the values of 37.3 and $8.6 \%$, respectively, for relative humidity. This is understandable, since there is the influence of solar radiation outside, and in some hours of the day the radiation falls directly on the thermo-hygrometer shelter.

The relative humidity of the indoor environment (1.6 meters) of the Soloteca in summer averaged $71.3 \%$. An hourly maximum value of $88.9 \%$, on December 17,2016 , was also observed in the indoor environment. It is worth noting that on several other days the maximum relative humidity was above $80 \%$. This information of relative humidity obtained inside the environment combined with the fact that the city of Rio de Janeiro has a hot and humid summer can be an indication of the need for dehumidification of the Soloteca of Embrapa Solos. As confirmed by Boone et al. (1999), during the warmer months this procedure may be necessary for places where reference soil samples are stored.

Figure 3 presents the statistical information of air temperature $\left({ }^{\circ} \mathrm{C}\right)$ and relative humidity $(\%)$ represented by the boxplot (Figure 3a). It can be seen that there is a greater dispersion of the data in the outdoor environment (“Ext.") for air temperature (Figure 3b) and relative humidity (Figure 3c), both for the minimum and maximum extremes and for the standard deviation. 
Figure 3. Statistical information (a) for air temperature (b) and relative humidity (c) using boxplot.

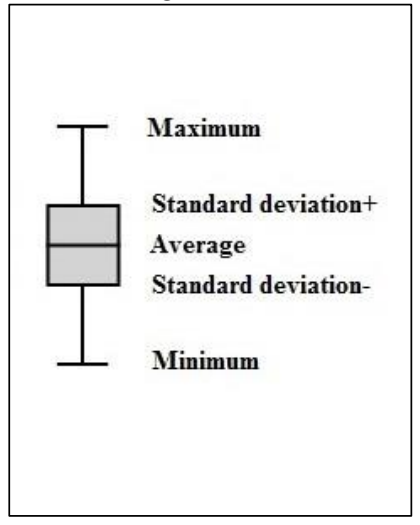

(a)

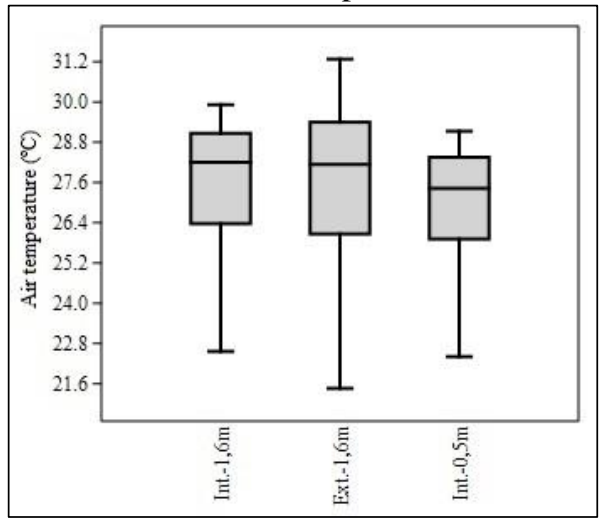

(b)

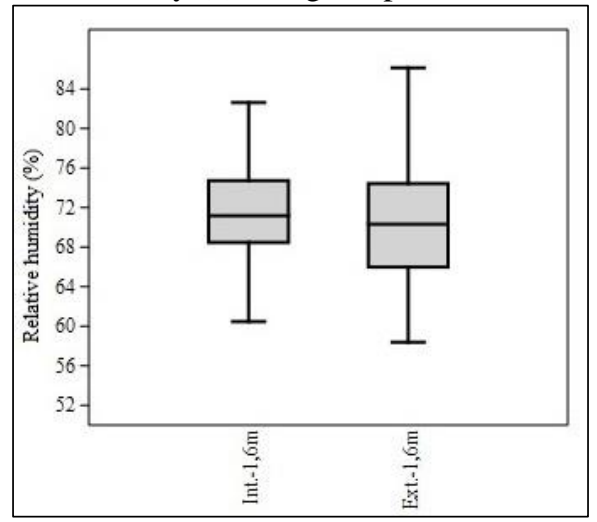

(c)

Figure 3 also shows that there is no difference between the averages of the indoor ("Int.") and outdoor environments (air temperature) at a height of 1.6 meters. The average minimum temperature was $26.9^{\circ} \mathrm{C}$ and was observed at the internal sensor, installed at 0.5 meters, indicating that the lowest temperatures were recorded near the surface. This trend was expected, since the cooler air, being denser, will concentrate in the lower part of the Soloteca.

The temperature variation indicated by the sensors at different heights reveals, even, that samples stored at the bottom of a given shelf will be under a different condition than samples stored at the top of this same shelf. Sousa et al. (2011), for example, showed the importance of ambient temperature on the amount of glomalin produced by arbuscular mycorrhizal fungi extracted from a Fluvisol and a Luvisol. Samples stored in a refrigerator $\left( \pm 4^{\circ} \mathrm{C}\right)$ showed up to $47.6 \%$ more glomalin than those kept at room temperature $\left( \pm 25^{\circ} \mathrm{C}\right)$.

\section{CONCLUSION}

Air temperature, on average, did not differ at a height of 1.6 meters between the indoor and outdoor environments, but there was a difference with the sensor installed near the surface.

There was no significant variation in micrometeorological conditions in summer 2016/17, however it would be interesting to observe the behavior of temperature and relative humidity in the summer of other years as well as in the other seasons.

The information presented in this paper is important due to the scarcity of literature presenting the ideal temperature and relative humidity limits for the storage site of reference soil samples. 


\section{ACKNOWLEDGMENTS}

To Embrapa Solos Technician Jorge Luiz de Gusmão, for the set of photographs of the Soloteca.

To the researcher Humberto Gonçalves dos Santos, who contributed so much to Brazilian Soil Science.

Our eternal gratitude goes to someone who was an honorable and dedicated professional. Certainly, he is today one of the stars that shine in the sky. 


\section{REFERENCES}

ALVARES, C. A., STAPE, J. L., SENTElHAS, P. C., GONÇALVES, J. L. M.; SPAROVEK, G. Köppen's climate classification map for Brazil. Meteorologische Zeitschrift, v. 22, n. 6, p. 711-728, 2013.

BOONE, R. D.; GRIGAL, D. F.; SOLLINS, P.; AHRENS, R. J.; ARMSTRONG, D. E. Soil sampling, preparation, archiving, and quality control. In: ROBERTSON, G. P.; COLEMAN, D. C.; BLEDSOE, C. S.; SOLLINS, P. (eds.). Standard soil methods for long- term ecological research. New York: Oxford University Press, 1999. chap. 1, p. 3-28.

COSTA NETO, P. L. de O. Estatística. 2. ed. São Paulo: Edgar Blücher, 266p. 2002.

FRIEDLAND, A. J.; CRAIG, B. W.; MILLER, E. K.; HERRICK, G. T.; SICCAMA, T. G.; JOHNSON, A. H. Decreasing lead levels in the forest floor of the Northeastern USA. Ambio,v.21, n.6, p.400-403,1992. Available at: https://www.jstor.org/stable/4313971?seq=1\&cid=pdfreference\#references_tab_contents. Accessed 10 Jun. 2019.

LAFORET, M. R. C.; LIMA, R. A. de; FAVARIN, A. M. Mémorias da Embrapa Solos. Rio de Janeiro: Embrapa Solos, 2014. 57 p. (Série Documentos, 176).

SOUSA, C. da S.; MENEZES, R. S. C.; SAMPAIO, E. V. S. B.; LIMA, F. de S. Influence of storage temperature and extractors on the determination of glomaline in Paraiban soils. Revista Ciência Agronômica, v. 42, n. 4, p. 837-841, 2011. 